\title{
A need analysis of development of implementation model of regional school operational assistance (Bosda)
}

\author{
Zulkifli $^{l}$, Suheni ${ }^{I}$, and Jaenam ${ }^{l}$ \\ ${ }^{1}$ STKIP PGRI Sumatera Barat, Padang, Sumatera Barat, Indonesia
}

\begin{abstract}
It is found widespread problems about the implementation of Bosda of Padang City, like the weakness of policy legality and delays in disbursement of funds. This research was carried out to reveal the needs analysis of real conditions in the field for the development of implementation model of Bosda in Padang City. This research was a preliminary study of research and development to get the model of development of Bosda implementation consisting of three stages; library study, field survey and modeling. However, this report was only up to the field survey stage in the form of needs analysis on implementation of Bosda. The findings indicated that the planning has not been referring to the material and non-material planning aspects, the implementation of Bosda is not supported by adequate socialization, cooperation of managerial, and commitment of Bosda recipient, and the evaluation has not fully covered the work program aspect and the implementation process of Bosda. The paper concludes that Bosda of Padang City is not implemented well. It was recommended that the managers should plan, implement, and evaluate the implementation of Bosda thoroughly and sustainably, so that the Bosda program can be realized well.
\end{abstract}

Key Words: Need Analysis, Bosda of Padang City

\section{INTRODUCTION}

The government has realized the invaluable contribution of teachers in improving the quality of education, because they are the components related directly to the process of education. In this regard, Verspoor as cited by V.T. Fadeyi, et.al. [1] found that teachers are the initiators, facilitators of teaching and learning activities. They act as agent of changes in any school system because of these roles they perform; they can be regarded as the heart of quality improvement strategy. It means, as one of the educational staff, teachers have a decisive role in the success of educational goals. In addition, teachers are given additional tasks in the structural positions of schools such as principals, vice principals, and homeroom teachers. The additional tasks have an impact on the decrease of teachers' task in implementing face-to-face teaching in the classroom. To address it, some of the schools recruit non-permanent teachers. Therefore, teachers need to carry out their duties and responsibilities well which are not only limited to the comparison of actual achievements that can be achieved with the work performance set but shows the various quality of the work done.

To be able to carry out their duties and responsibilities properly, the government has to give more attention to the teachers such as the improvement of welfare in the form of giving the right reward. A. D. Timpe [2] stated that to change and improve someone's performance there must be rewards, because people will change if they see any rewards, such as increases of salary, increases of responsibilities, praise, and special assignments. 
Adequate income will affect someone's performance then there is satisfaction in working. As E. A. Locke and G. P. Latham [3] theory opined that a satisfied worker will produce more and use this as a basis for relating motivation, satisfaction and job performance. The need to motivate workers is a fundamental issue in all organizations that are aimed at achieving set goals. Teachers like workers in other organizations, need the renewed energy brought by incentive from time to time if they are to perform effectively.

To improve teachers' welfare as an effort to improve the quality of education is required a sustainable education development strategy from the government. In this regard, V. T. Fadeyi, et.al. [1] found that there is sifnificant relationship between teacher salary, promotion and students academic performance. If necessary attention is given to teachers' welfare, this will bring about positive development in the educational system. It is hereby recommended that teachers' welfare scheme should be of paramount focus to the educational policy makers and administrators. They also recommended that teachers should be placed on meaningful salary scale and given opportunities to further receive training in their various disciplines for better performance to be achieved. In line with V.T. Fadeyi, et.al., F. Luthans [4] posited that welfare schemes are the strategies employed in motivating teachers for better job performance. These are in form of salary increment, gratuity, regular promotion, ensuring job security, and establishing cordial relationship among teachers.

In a related study, N. Frances, et.al. [5] examined how school welfare provision influences teacher performance. The findings are that school administrators provide only those welfare programmes that have a direct bearing on task accomplishment. Second, teachers' performance is high mainly on examination management, punctuality, and cocurricular activities. Third, school welfare provision is however too insignificant to cause a remarkable teacher performance. They concluded that school welfare provision will positively influence teacher performance if teachers are reciprocally committed to work and administrators meet teachers varied needs.

The concept of welfare is concerned with the total wellbeing of employees both at school and at home. H. Dale-Olsen [6] specifically defines school welfare as referring to teachers' health status and happines, as well as their safety, although he does not provide what constitutes teachers' happiness. In his research, H. Dale-Olsen [6] observed a positive correlation between wages and fringe benefits. Higher wages and more fringe benefits reduce the worker turnover rate. According to B. J. Keitany [7], the provision of well-being to teachers is a source of earning and satisfaction which is likely to increase their productivity because they are motivated and happy.

As a form of awareness of the government of Padang city in improving the quality of education through the improvement of teachers' welfare, it has been established the Regional Medium Term Development Plan (RMTDP) of Padang City by 2014-2019 which is primarily aimed at improving the quality and equity of education. With the RMTDP, the government of Padang City has done regulation in the field of education, by issuing Regulation of Mayor of Padang Number IA by 2015 on the amendment to the Regulation of Mayor of Padang Number 17 by 2014 on the Regional School Operational Assistance (Bantuan Operasional Sekolah Daerah, Bosda), and Decision of Mayor of Padang Number 82 by 2015 about the amount of Bosda. Bosda is the funds provided by the local government that is not accommodated by the School Operational Assistance (Bantuan Operasional Sekolah, BOS) from the central government that is especially prioritized for improving the welfare of principals, vice principals, homeroom teachers, non-permanent teachers and non-permanent employees with the aim of improving performance and quality of education services. The implementation of Bosda is more emphasized on improvement activities of education quality in the form of additional income for principals, vice principals, homeroom teachers, non-permanent teachers and non-permanent employees. 
Based on the opinions above, the purpose of this study is to find the data about the implementation of Bosda in Padang City.

\section{Theoretical Study}

Educational policies are initiatives mostly by governments that determine the direction of an educational system and increase the quality of life of a people. A policy or regulation does not have to be rigid, as there should be room for adjustment if necessary after its formulation. Hoy and Miskel as cited by N. S. Okoroma [8] believe that "policies are not only formulated but also programmed, communicated, monitored and evaluated". The nonrigid nature of policies is confirmed by Lindblom as quoted by N. S. Okoroma [8] when he describes policymaking as a "process of successive approximation to some desired objectives in which what is desired itself continues to change under reconsideration". In fact, a good policy is one that can be reviewed as the need may arise. Lindblom believes that a wise policy maker cannot expect all their policies to achieve a one-hundred percent success. Regardless of how good a policy may be, its implementation may introduce some element of imperfection.

The realization of a regulation is mostly influenced by the level of implementation in the field. The implementation here is how to manage the funds of Bosda in order to be implemented well. In managing a program, there are various concepts presented by experts as in the following table:

\begin{tabular}{|l|l|l|l|}
\hline \multicolumn{1}{|c|}{ Table 1. Aspects of Management } \\
\hline Fayol & \multicolumn{1}{|c|}{ Terry } & \multicolumn{1}{c|}{ Koontz } & \multicolumn{1}{c|}{ L. Gullick } \\
Planning & Planning & Planning & Planning \\
Leading & Organizing & Organizing & Organizing \\
Controlling & Actuating & Staffing & Staffing \\
& Controlling & Directing & Directing \\
& & Controlling & Coordinating \\
& & & Reporting \\
& & & Budgeting \\
\hline
\end{tabular}

Source: S. Danim [9]

For this study, the management discussed is based on the management applied by the Bosda managers, that is adopting the concept stated above, with aspects of planning, implementation and evaluation of Bosda implementation. Planning is a process of thinking, selecting, and linking knowledge, facts, imaginations and assumptions for preparing a set of desirable decisions in the future. According to Henri Fayol as cited by C. W. L. Hill and S. L. McShane [10], "planning is a formal process whereby managers choose goals, identify actions to attain those goals, allocate responsibility for implementing actions to specific individuals or units, measure the success of actions by comparing actual results against the goals, and revise plans accordingly". And according to Beishline as quoted by $\mathrm{M}$. Manullang [11] Planning determines what should be achieved (timing qualitatively) and when it should be achieved, where it should be achieved, how it should be achieved, who is responsible, and why it should be achieved. Planning activities focus on maintaining goals.

From the above opinion, it can be concluded that the planning is useful to provide clear direction for each activity, so that every activity can be cultivated and implemented as efficiently and effectively as possible. To be able to provide a clear direction, the planning should refer to the aspects of determining needs, formulating goals, setting goals, and revising planning.

The aspect of planning is more related to the abstract aspects of the management process, while the implementation emphasizes the activities directly related to the people in the program. Implementation of the bosda is an effort to make the planning become a reality, through the socialization, cooperation and commitment so that every activity can be 
implemented optimally in accordance with the roles, duties and responsibilities of program implementers.

Practically, the implementation is an effort to create a climate of cooperation among the staff of the program implementing so that the organization's goals can be achieved effectively and efficiently. The last aspect of Bosda implementation is evaluation activity. Evaluation is a systematic and planned activity to measure, assess and classify the implementation and success of the program. In general, the term of evaluation can be equated with the appraisal, scoring, and grading; the words that indicate attempting to analyze the policy outcomes in terms of unit of value. Specifically, evaluation is concerned with the production of information on the value or benefits of policy outcomes (W. N. Dunn, [12]). While, S. Arikunto [13] stated that evaluation is an activity to collect information about the operation of something, then the information is used to determine the right alternative in making decisions.

The main function of evaluation in this case is to provide useful informations to determine the policy to be taken based on the evaluation that has been done. Evaluation activities are the fairest way to determine the rewards for employees. Evaluation of work aims to ensure the achievement of goals and objectives. Besides, the purpose of evaluation is to know the position of activities both associated with the program that has been established and the ongoing process.

Evaluation can provide good and correct information. Giving criticize on clarification of a value of a goal and target, then create a policy method to achieve performance so that evaluated programs and activities contribute to reformulating the policy of an activity in the implementation of Bosda. The most important thing in evaluating the program and the process is how to know the deviations that occurred as early as possible, both in the planning and the implementation stages so that it can be done anticipation, correction and adjustments as soon as possible in accordance with the situation, condition and progress of the program.

\section{METHODS}

This research was a preliminary study of a research and development proposed to obtain the needs analysis in finding hypothetical model of Bosda implementation of Padang City. Sukmadinata [14] said that preliminary study in a research and development consisted of three stages, namely library study, field survey and modeling. However, this report was only up to the field survey stage. Library studies were conducted to examine the concepts and theories related to the model of Bosda implementation, while the field survey was conducted to collect the data. Furthermore, from the data analysis obtained from the field survey and refer to the concepts and theories that have been studied, it can be found problems or needs that will be used to find hypothetical model of Bosda implementation.

To obtain quantitative data through questionnaires, the sample was representative of headmasters, vice principal, homeroom teachers, non-permanent teachers and nonpermanent employees receiving Bosda assistance, determined by purposive random sampling. While, for the qualitative data through interview, the informant was the manager of the Bosda. Data analysis performed on each component was different, in accordance with the objectives of the research to be achieved systematically. In this regard, Bogdan as cited by L. J. Moleong [15] stated that data analysis is a systematic process of searching and compiling transcripts of interviews, field notes, and other materials that have been collected to improve understanding and allow someone to present what he has found to others.

\section{RESULTS AND DISCUSSIONS}


The empirical data found in this research indicated that the Bosda policy had been implemented optimally, but there were still many technical obstacles faced. The obstacles came from the implementation process, both in the aspects of the planning, implementing, and at the evaluation stages. These conditions had an impact on the achievement of Bosda goals.

\section{Description of Planning Data}

In planning aspect, it is known that the indicator of determination of needs was not good, the indicator of formulating the objective was good enough, the indicator of setting target was not good, and the indicator of revising planning was good enough. It means that the overall indicator of the planning has not been implemented well. Problems in the planning aspect are the factors that influence the implementation of the Bosda. According to Beishline as quoted by M. Manullang [11], planning determines what should be achieved and when it should be achieved, where it should be achieved, how it should be achieved, who is responsible, and why it must be achieved.

From the above opinion, it appears that planning is essentially an activity of thinking of a better future, which describes the change, both quantitatively and qualitatively compared with the previous situation or current conditions. The Bosda planning process should be based on the real issues that occur in the field. The problems in planning are directly related to the problems of achieveing the objectives that have been formulated. It is very clear that the planning process is the starting point for the implementation of Bosda program in improving the quality of education.

\section{Description of Implementation Data}

The findings of the research on the implementation aspect showed that from the three indicators found the answer that the socialization activities were not implemented optimally, the cooperation was not done well, and the commitment was not good category. Socialization activities in the implementation of Bosda aims to equate perceptions in the implementation of activities so that the set targets can be achieved in a timely, effective and efficient manner. Socialization refers to all factors and processes that make each program to be aligned in implementation. It is important because if socialization is not done optimally, the goals of the program will be difficult to be achieved.

Socialization can realize solid cooperation. However, because the socialization activities were not implemented optimally, the synergic cooperation can not be achieved. Cooperation in the implementation of the Bosda is defined as an activity conducted jointly to achieve common goals. It means a job or action undertaken by each party in order to achieve the goals or targets that have been previously planned and also mutually agreed. Cooperation will arise if a person or group is aware if they have the same interests and at the same time. People who work together will have the knowledge and awareness to fulfill all responsibilities. It means that cooperation is a combination of various different areas in implementing a program that has the same goal. This cooperation will usually take time because the different areas have different workflow, but because it has the same purpose so that cooperation can be implemented.

Commitment was one of the factors that influence the level of achievement of Bosda implementation. It can be seen from the findings that the respondent's answer was in not good category. Based on the above conditions, the commitment should be a special attention because the commitment is a demand to each individual in accordance with his duties and functions in implementing Bosda.

\section{Description of Evaluation Data}

In determining a decision on what has been and will be implemented in the implementation of Bosda required program and process evaluations. The findings of the study indicated that 
the evaluation of the programs undertaken in the implementation of Bosda had not been done well and the evaluation of the process had not been implemented well, so every year the bosda recipient receives the same complaints.

The systematic evaluation need to be done in order the program can be implemented well. H-T. Chen [16] argued that program evaluation is the application of models, techniques and knowledges of evaluation, to assess and refine planning, implementation and effectiveness of a program systematically. In line with that, S. Arikunto [13] defined that the evaluation program is a process to determine whether the objectives of the program has been realized. Evaluation program is the process of determining the value, purpose, effectiveness or compatibility of something in accordance with the criteria and goals set previously. Further, the evaluation of the program aims to collect information regarding the implementation of the program used to conduct follow-up or decision-making activities. Thus, the process of program evaluation in the implementation of Bosda should be based on careful comparison to the data being observed by using certain standards that have been standardized.

Process evaluation involves targeted, planned, and systematic efforts to examine the process of implementing Bosda. Based on the findings indicated that the evaluation process was not performing well. A well coordinated program is mostly influenced by the extent to which the activity process can be evaluated thoroughly. Process evaluation should be done as well as possible. This is important because the results of process evaluation will be used as a consideration in future decision making. Process evaluation should be directed to control the achievement of the objectives and level of task control by the bosda implementers. By evaluating the process, it can be known the level of efficiency of the implementation activities, both in terms of strengths and weaknesses, so as to provide feedback in order to improve the implementation of Bosda.

\section{CONCLUSION}

Based on the findings and discussions that have been described above, it can be concluded that the needs analysis of the field conditions in the implementation of Bosda, found that in the aspect of planning with indicators of determining needs was in not good category, the indicator of formulating the objectives was in good enough category, the indicator of setting target was not good, and the indicator of revising planning was good enough.

The aspect of Bosda implementation on the indicators of socialization were not implemented optimally, the cooperation was not done well, and the commitment was not good category. Meanwhile, on the evaluation aspect, both program evaluation and process evaluation have not been implemented well.

It means that the overall indicators of planning, implementation, and evaluation of the implementation of the Bosda need to be addressed thoroughly and sustainably, so that the Bosda program of Padang City can be realized well. The implication is with the findings of this field condition, will be a reference in developing hypothetical model of Bosda implementation of Padang City.

\section{ACKNOWLEDGEMENTS}

I wish to acknowledge the management of STKIP PGRI Sumatera Barat and education department of Padang City for providing a chance for me to undertake this study. I also thank to the participants in this study for accepting to provide me with useful information that has greatly determined the success of this study.

\section{REFERENCES}


1. V. T. Fadeyi, A. O. Sofoluwe, and R. A. Gbadeyan, APJEAS, Influence of Teachers' Welfare Scheme on Job Performance in Selected Kwara State Secondary School, 2, 4, 89-93 (2015)

2. A. D. Timpe, , Manajemen Sumber Daya Manusia. Jakarta: Media Komputindo (1994)

3. E. A. Locke, and G. P. Latham, Academy of Management Review, What Should We do about Motivation Theory? Six Recommendations for the Twenty-First Century, 29, 3, 388-403 (2004)

4. F. Luthans, Organization Behaviour (10 ${ }^{\text {th }}$ Edition), Boston: Mc Graw Hill/Irwin (2005)

5. N. Frances, S. Denis, and O. Vincent, IJEPRR, The Interplay of School Welfare Provision and Teacher Performance: The Case of Ugandan Secondary Schools, 3, 1, 6-13 (2016)

6. H. Dale-Olsen, Labour Economics, Wages, Fringe Benefits and Worker Turnover, 8, 1, 87-105 (2006)

7. B. J. Keitany, Perceived relationship between Employee Welfare Programmes and Employee Performance at Kenya Pipeline Company.Unpublished Masters of Business Administration Thesis, Nairobi University Press (2014)

8. N.S. Okoroma, Australian Journal of Adult Learning, Educational Policies and Problems of Implementation in Nigeria, 46, 2, 243-263 (2006)

9. S. Danim, Profesi Kependidikan, Bandung: Afabeta (2010)

10. C. W. L. Hill and S. L. McShane, Principles of Management, New York: McGrawHill/Irwin (2008)

11. M. Manullang, Dasar-dasar Management, Yogyakarta: Gajah Mada University Press (2008)

12. W. N. Dunn, Pengantar Analisis Kebijakan Publik, Jakarta: UGM Press (2003)

13. S. Arikunto, Dasar-dasar Evaluasi Pendidikan. Jakarta: Bumi Aksara (2008)

14. Sukmadinata, Landasan Psikologi Proses Pendidikan. Bandung: Rosdakarya (2005)

15. L. J. Moleong, Metodologi Penelitian Kualitatif: Bandung: Rosdakarya (2007)

16. H-T. Chen, Practical Program Evaluation: Assessing and Improving Planning, Implementation and Effectiveness, London: Sage Publications (2005) 